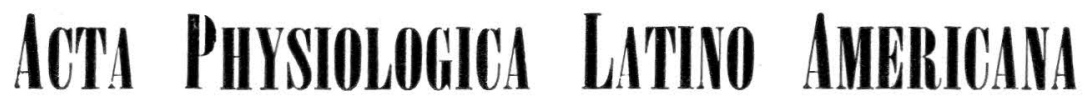

Organo de la

Asociación Latinoamericana de Ciencias Fisiológicas

\section{BERNARDO ALBERTO HOUSSAY}

(1887-1971)

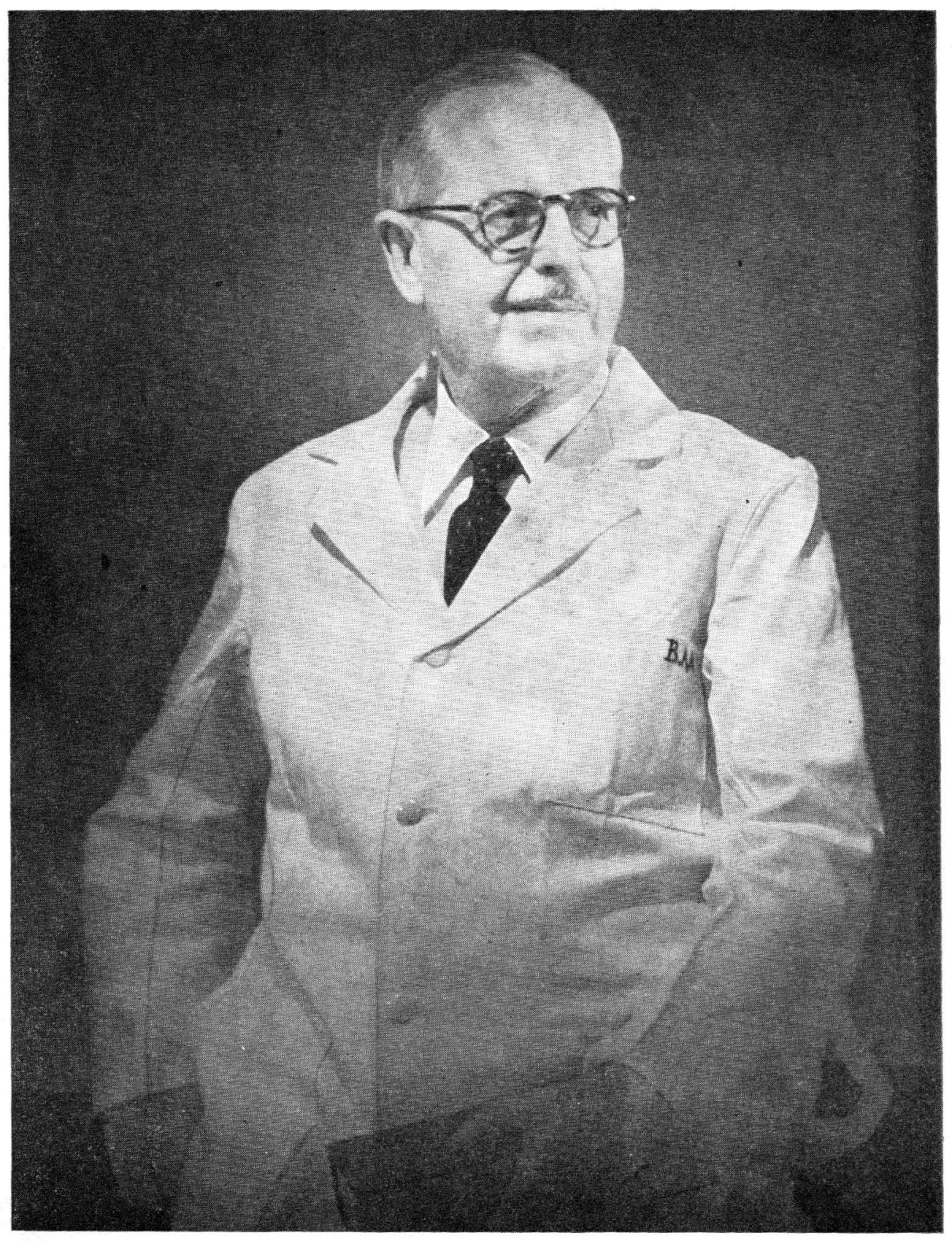




\section{HIS EARLy yeARS. HIS FAMILY}

The parents of Bernardo Alberto, Alberto Houssay and Clara Laffont, were born in the South of France, the former in Bayonne and the latter in Aussanes-Angles (Hautes Pyrénées). They married in Argentina and a daughter was born. Soon after, they returned to France as Alberto Houssay's baccalaureate obtained in France was not recognized in Argentina. In Bordeaux, Alberto Houssay graduated as a lawyer and Doctor in Law. There two sons were born.

In 1886 they returned to Argentina, specially invited by the then President of the Nation, Nicolás Avellaneda. Alberto Houssay was at once appointed professor in the Central National College, the only secondary school existent at this time in Buenos Aires. His decision to return to Argentina was made easier as he not only knew the country already but the Laffont family had settled here.

The fourth child, Bernardo Alberto, was born in Buenos Aires on the 10th of April, 1887. Later, four more children were born, all argentines. As well as the education he always received in his own home, Bernardo was sent from 5 to 8 years of age to private schools and then to the State elementary school where he finished the course at the age of 9. On the advice and authorization of his masters and directors he sat for the entrance examination of the lst year of the National College, passing as an external student.

The three eldest children had been sent to finish their education in France. There the two boys received their baccalaureate and the daughter graduated as a school teacher but in view of the fact that the change had not brought about any remarkable results and also because the cost was so high, the parents decided that Bernardo should remain in Argentina. The result in this case was note- worthy; baccalaureate at 13 years old with the highest classifications in the course.

Evidently Bernardo was a precocious child. At this age he spoke French correctly and was conversant through his father with the classical writers whose works he committed to memory and could quote accurately and with pleasure many years later. Already he showed a passion for reading especially history, literature and natural science and he also revealed his extraordinary memory, his mental elasticity, his balanced judgment and his devotion to work.

\section{His Academic Formation} (1901 - 1910)

Bernardo Houssay's university career was spread over the years 1901 to 1910 as he started the career of Pharmacy in 1901 and finished in 1910 his degree as a Doctor in Medicine.

$\mathrm{He}$ graduated as a pharmacist in 1904 when only 17 years old, and was top of the course. These studies gave him the foundation in chemistry which was so useful in his later career. As time passed Houssay was responsible in great measure for the development of the career of Biochemist in the University of Buenos Aires, and under his direction biochemists of high rank were formed, many of whom became university professors later.

He at once began his medical studies. $\mathrm{He}$ was an outstanding student and many of his examinations were remembered for a long time as he had been congratulated by the examining board. In 1908 he was appointed by competitive selection as assistant in practical work to the Chair of Physiology. The professor of Physiology, Horacio G. Piñero ordered the publication of the classes given by him. This contact with physiology favoured his vocation, never to be abandoned later. He observed at 
termination to consecrate himself to the study of Physiology. He knew the principles of experimental methods from his reading of Claude Bernard's book which had so impressed him. He had had his first contact with the speciality in the Physiology Department of the Faculty of Medicine, first as a student and then as assistant from 1908 to 1910 . But now the Faculty of Veterinary Science gave him his best chance to deepen his knowledge. His vocation for the natural sciences and his conviction that the development of physiology would benefit medicine in gencral, reinforced his point of view. He decided he would become a physiologist and from thence forward he regarded his vocation as a patriotic duty.

This was another characteristic of his personality which also strengthened at this time. He made up his mind to become a scientist but in his own country whose development he wished to advance. It is well known that Houssay never accepted in all his life even in its darkest moments and in spite of most advantageous offers, any position abroad. His serene and constructive patriotism is an example younger generations may well remember.

\section{Houssay, medical practitioner}

As soon as he graduated, Houssay began to practise his profession as was the custom then (1910), but also as a means to earn money. He had a consulting room and for several years attended private patients. At the same time he attended the hospital. At first he was a house physician but his outstanding merits as such soon led to his appointment as chief of the clinical medicine unit in the Alvear Hospital (1912-1917). Several patients suffering from endocrine lesions came under his notice here, and his preoccupations are expressed in the publication of various clinical cases which can be read in his bibliography.

Later he gave up both consulting room and hospital work entirely though he encouraged others from the physiological point of view to study and solve clinical problems. As examples of these may be mentioned the study of Ayerza's cyanotic heart syndrome (with L. Solari and A. Berconsky), arterial hypertension, diabetes, goiter, etc.

\section{Houssay, Professor of Physiology in the Fagulty of Veterinary SaIENCE (U.B.A.)}

This period of Houssay's life had transcendental importance over his future career, as during it he was able to acquire experience in teaching and research while his ideas were ripening.

His promotion to the Chair of Physiology in the Faculty of Veterinary Science occurred at the early age of 22 on the suggestion of a great personality of those days, Professor Pedro N. Arata. Professor Arata knew of Houssay's outstanding merits as a student and his exceptional vocation for the natural sciences and he specially remembered the brilliant examinations given by Houssay in Organic Chemistry. He knew the Chair of Physiology in the Faculty of Veterinary Science was vacant and proposed that Houssay should be appointed; thus, Houssay was made acting professor first and then full Professor from 1912 to 1919 when he resigned in order to take up the Chair of Physiology in the Medical Faculty.

$\mathrm{He}$ thus became a University Professor of the same age as or even younger than, most of his students. At first the students resisted his appointment on the grounds he was not a graduate of their faculty and also because of his age; however they decided to attend his first class as a try-out. $\mathrm{He}$ so impressed them with his theoretical knowledge and the accompanying prac- 
ders in Argentina and he was able years later to prepare a protective serum for its toxin.

\section{Marriage With Doctor María Angéliga Cíatán}

These studies on snake and spider bites brought about a special result. The material for them was obtained for him by a distinguished doctor in chemistry, María Angélica Catán. This professional relationship ended in their marriage in 1920. Three sons were born, Alberto, Héctor and Raúl, all brilliant students and doctors of medicine.

María Angélica Catán was his inseparable companion until her death in 1962. She was the understanding help mate who encouraged him and supported him throughout the economical strain of being a "full time" physiologist. Thanks to such an exemplary wife Houssay was able to dedicate himself completely to his Science, so that his efficiency, already great, became extraordinary. She was able to divide her job of bringing up the children with that of a wife who helped her husband in anonymous tasks, sometimes thankless, necessary for his work. Thus she filed articles and reviews, she corrected proofs, she gave her ideas on experiments, she knew his collaborators, and she put up with their straightened circumstances without complaint.

She was always the unknown force, the invisible mainstay of the home. Her disappearance after a long and distressing illness left a deep sorrow which her husband never overcame.

The Institute of Physiology $(1919$ - 1943)(1945 - 1946)(1955 - 1957)

Houssay was incorporated into the Faculty of Medicine of the University of Buenos Aires (U.B.A.) in 1919 as Professor of Physiology. In spite of his qualifications, his nomination by the
Directing Council was not plain sailing. There was a tie in the voting which was settled in his favour by the casting vote of the Dean, Professor Alfredo Lanari.

$\mathrm{He}$ soon resigned his professional practice and other commitments, thus becoming "full time" in his chair which was now converted into an Institute of Physiology, that is to say, with teaching and research laboratories and the possibility of the Professor and other personnel on a "full time" basis. This change meant a decided economical loss as the emoluments he received from the resigned posts gave him a much larger income.

As time passed collaborators appeared who, following his example, also worked "full time" at the Institute. Such "full time" dedication grew but surely in Argentina and many other Latin American countries.

Soon the Institute of Physiology had achieved international fame and Dr. Carlson, the eminent North American physiologist in a now classical phrase expressed the fact that: "Houssay has put Argentina on the physiological map of the world".

$\mathrm{He}$ worked in a remarkable way in the organization and development of the Institute over this long period of nearly $1 / 4$ of a century. There he gave both theoretical and practical teaching to the medical, dentistry and pharmacy students. He continued and developed scientific researsh in the fields he had begun in the former period and started further experimental investigations. $\mathrm{He}$ formed many disciples who at a given moment in their preparation were sent to suitable centres abroad so they might import later, new knowledge. He wrote, published and lectured, always in a clear and simple style with no rhetorical flourishes, yet convincing by the certainty of their expositions. This untiring multitude of activities which seemed those of an army rather than only one individual demonstrated his tenacious 
In Biological Physics: Enrique Di Benedetto, Juan J. Rossignoli, Enrique Savino and Raúl Wernicke.

In Physiology: Enrique Aubrun, Virgilio G. Foglia, Juan T. Lewis, Máximo Magenta, José B. Odoriz, Oscar Orías, Octavio Pico-Estrada, Horacio Rubio, and Luis A. Solari.

\section{His aGtivity in Research}

The Institute of Physiology soon acquired national and international fame because of the high quality of the scientific research carried out there. Concurrently the prestige of its director continued increasing, and he was sought more and more by the great foreign centres, while his words were considered in ever increasing scale in Argentina.

The daily routine of the Institute began at 8 a.m. when he met the 7 or 8 representatives of the principal sections, inquiring if they had anything to report, and giving the necessary orders. $\mathrm{He}$ would then inspect the rooms where practical work took place and then the laboratories. At eleven he lectured. $\mathrm{He}$ started experimental work at 2 in the afternoon and would finish about 5 p.m. at which time he would receive visitors. Later he had appointments with his research workers or attended lectures and scientific meetings or brought his reading up to date.

$\mathrm{He}$ was indeed indefatigable. According to his own confession "he would rest by changing his work", and he was luckily helped by his excellent health. Nevertheless he had an internal stimulant - his love for his chosen Sciencewhich ever urged him on.

In his daily inspection of the Institute he would ask each research worker how he was getting on. If the worker was not in his place he would leave a paper with the question written on it.* If he

* He would usually write the note on a piece of used paper or the corner torn off a newspaper, an indication, as his research workers remarked, of his parsimonious French spirit. was answered there was nothing to report he would often say "this was little for a scientist".

It was very interesting to discuss the research in hand, with him. His bibliographical information on the problem, his calm judgement of the results, his relevant criticisms and his quick and fertile imagination for the planning of new experiments could be intimately appreciated. This complex of qualities made up the scientist Houssay, so many outstanding qualities united in one person, combined with his disinterested willingness to give ample help towards solving any probıem.

\section{THE FORMATION OF DISCIPLES}

Such an outstanding personality was bound to attract young men and form many disciples. Hundreds of scientists came under his influence and can be considered his followers. Amongst them many worked with him in his laboratory while others, no less important, worked outside. By means of this galaxy of brains he was able to wield a vast influence on the development of science and on medical education in Argentina and other countries, especially those of Latin America. In this way not only the progress in physiology but also that in pharmacology, histology and biochemistry was the result of his influence. Many specialities also were benefited such as endocrinology, cardiology, nutrition, neuro-physiology and so on.

Many of his followers came from abroad among whom may be mentioned: Bolivia: Luis F. Hartmann.

Brazil: Pery Riet-Corrêa, Eduardo M. Krieger, José Leal(father), Thales Martins, María Marques, Renato Migliorini, Demosthenes Orsini, José Ribeiro do Valle, Clotilde Souto-Maior, Naide Theodosio, Edgar M. Wagner.

Canada: Christianne Dosne.

Chile: Julio Cabello-Ruz, René Honorato Cienfuegos, Bruno Günther, Fer- 
evident. Rectors, deans, professors, students all over the country started hostile acts which increased in violence leading to paralysis of the universities and confrontations of antagonistic groups. This attitude had to be suppressed.

The first measure was to dismiss Professor Houssay and numerous other university professors for having signed a manifest together with many other distinguished people, declaring that the country should return to "constitutional normality, effective democracy and american solidarity".

The dismissal of Professor Houssay from the Institute of Physiology (October 1943) caused amazement. It was incredible considering his scientific eminence and his position as its creator and inspiration. His collaborators in the Institute were divided into those who resigned following their leader, and those who decided to remain in the effort to preserve it for its future recuperation. Similar reactions took place in other universities all over the country.

The dismissal of the professors exacerbated the political situation. As a consequence faculties were taken over by the students, skirmishes occurred between antagonistic armed groups and a large number of pupils were jailed as political prisoners. The authorities were obliged to close all places devoted to higher education.

The future for argentine physiology could not have been more tragic; at the same time as Buenos Aires, the chairs of physiology in Rosario and Córdoba, held by Professors Juan T. Lewis and Oscar Orías respectively, also became vacant. Here also their collaborators resigned emphasizing the paralysis of the laboratories dedicated to research. And now the persecution of those who had been expelled began and many were jailed. There were no other centres which could absorb those dismissed, thus many physiologists returned to private practice while others went abroad.

Professor Houssay decided that under the circumstances he must do all he could to stay in his own country as the standard bearer for science. During these days of conflict and oppression he was asked by the students to compose a kind of "credo", which was widely circulated, in which he expressed his convictions with courage and firmness. It read as follows:
I love my country
I love freedom
I believe in personal dignity
I believe in doing one's duty
I am devoted to Science
I am devoted to work
I respect Justice and my fellow men
I feel affection for my family, followers and friends

Bernardo A. Houssay, Buenos Aires, October 1943.
He soon realized that his person ran serious risks. He had difficulty in consulting books in the Faculty and once in December 1943 when I went with him to operate a sheep in the Faculty of Veterinary Science we were prevented from doing so. Pamphlets were distributed insulting him and a bomb exploded in his house one day which, though no one was hurt, caused considerable material damage.

In 1945 there was a general amnesty for the hundreds who had been expelled from the universities in 1943 and many returned to their posts, but almost immediately the same problems occurred 
breeding of rats was begun and dogs, toads, etc., were bought.

Soon it was working. Unfortunately it was necessary to recommence all research since the requisite material in the Faculty had been completely destroyed during the disturbances; nevertheless Dr. Houssay's dynamic powers soon organized scientific meetings, and experiments on the following were carried out: the excitability of the myocardium, (Orías) ; the mechanism of experimental arterial tension (Braun-Menéndez); experimental diabetes (Lewis and Foglia); Leloir on problems of biochemistry relating to the metabolism of carbohydrates.

Virgil's dictum was never more appropriate: "Unceasing travail and the sharp sting of adversity will overcome anything!"”

To the first group of workers were presently added new researchers, some who came from abroad and others who worked part-time. Among the former were Carlos E. Rapela and María Gordon who worked on catecholamines; Miguel R. Covián, neurophysiology; Carlos Martínez, experimental diabetes. Amongst the part-time workers were Roberto M. Pinto, ovary; Juan C. Penhos, vitamines; Adolfo Cardeza, histology; Carlos Galli-Mainini and N. Ambrad-Domínguez, reproduction; to mention only a few.

The removal of the Institute to its new and present premises (Obligado 2490 ) in Belgrano, in 1959, was of great advantage from the point of view of space. Now equipment could be properly accommodated. Groups of young research workers could labour under Houssay's direct supervision in such varied fields as the metabolism of steroids (Jorge Blaquier, Mónica $\mathbf{S}$. de $\mathbf{C a}$ meo, Eduardo Charreau, Alejandro de Nicola, Florencia Galli, Elena A. Bernard, Osvaldo Irusta and Guillermo Wassermann); neurophysiology (Sergio D'Agostino, Alberto de Juan, Alicia Den- ti, Juan R. Depaoli, Diana J. de Hardy, Wenceslao E. Hartmann, Alejandro Kacelnik, Elena Lascano, Jorge A. Negroni, Néstor Schmajuk and Enrique $T$. Segura); renal hypertensor substance (Julia Uranga); immunity (Elsie M. E. de Chirico and Raúl Houssay); diabetes (Enrique J. del Castillo, Alicia G. Roldán and Ciro T. Rietti).

The scientific output was always considered of high quality and importance both in this country and abroad, thus the Institute acquired and kept the prestige its director was able to bestow upon it.

Some of Houssay's outstanding disciples formed private laboratories similar to the Instituto de Biología y Medicina Experimental, devoted to non-profit scientific research. These were the "Instituto de Investigaciones Bioquímicas" (Buenos Aires), under direction of Dr. Luis F. Leloir, the "Instituto de Investigación Médica" (Córdoba), under direction of Dr. Oscar Orías, the "Instituto de Investigaciones Médicas" (Rosario), under direction of Dr. Juan T. Lewis, and the "Instituto de Neurobiología" (Buenos Aires), under direction of Dr. Juan H. Tramezzani.

While Houssay directed the Institute from 1944 to 1971 , several outstanding happenings which merit special mention occurred:

a) the guiding role it kept in the formation of valuable research workers and scientific output.

b) the appointment of many of its research workers as university professors in Argentina and abroad.

c) the publication of the text-book of Human Physiology by Houssay and his collaborators.

d) the award of the Nobel Prize in 1947 -an extraordinary event which will be dealt with later.

e) the creation by Houssay of the National Council for Scientific and Technical Research (Consejo Nacional 
his encouragement of the creation of the Latin American Society of Physiological Sciences not only brought about a concurrence amongst our countries but also the establishment in each Congress of a session for the discussion of problems in the basic sciences.

His articles and books for the spreading of scientific knowledge and for teaching have also played a great part in awakening an interest in such knowledge. It is sufficient to remember his "Human Physiology" which was first published in 1945 and represented the valuable efforts of Houssay and a group of his more intimate collaborators. The first edition was followed by several others, both in Spanish and other languages.

His collaborators necessarily changed as the years went by but he found them always wherever he was working, some veterinary workers, others chemists, doctors, dentists, etc., with different scientific formations, yet all contributing to the common weal with their specialized knowledge. This shows the wide embracing spirit of the Master who knows how to find and unite individual efforts.

Certain examples of the subjects of original research which Houssay followed through many years with different collaborators and techniques will now be enumerated.

\section{THE HYPOPHYSIS AND GARBOHYDRATE METABOLISM}

Houssay's name will always be linked with the hypophysis, the pancreas and diabetes. This relation was established early on in his career. According to his own words he had the opportunity of examining in 1907 a patient with acromegaly who impressed him deeply. He knew that the hypophysis was affected and his anatomical studies had made him familiar with the gland. Little was known as regards its function so he decided to study it. In 1910 he published his first work on the subject and in 1911 his thesis for his Doctorate in Medicine which received the Faculty Prize*. From thence forwards he worked continuously researching on the hypophysis.

When insulin was discovered in 1921 by Banting and Best, he initiated with different collaborators a systematic study of its physiological action in cases of hyper or hypofunction of the adrenals, the thyroids, etc. $\mathrm{He}$ observed many notable changes but what impressed him most was the extraordinary sensitivity to insulin produced by hypophysectomy. This was found in collaboration with Potick, Magenta, Rietti and Mazzocco, and it was confirmed and substantiated by further experiments. In 1929 he demonstrated with Potick the reverse, that is to say, that injection in the toad of extract of the anterior lobe of the hypophysis, caused resistance to insulin. Evidently the anterior hypophysis modified the sensitivity of the organism to insulin.

As the blood sugar varied greatly under the influence of insulin, he postulated that the results observed were due to variations in the utilization of the sugars following hypophysectomy or administration of anterior hypophyseal extracts. Following this line of thought with Biasotti (1930) he took a pancreatectomized diabetic dog and removed its hypophysis**. An astonishing improvement in the diabetes of the dog occurred. The blood sugar diminished and it survived months while the controls in which pancreatectomy alone had been performed only survived operation

* Houssay, B. A.: Estudios sobre la acción de los extractos hipofisarios. Ensayo sobre la fisiología del lóbulo posterior de la hipófisis. Tesis. A. G, Buffarini Editor. Buenos Aires, 1911, 190 pp.

* Houssay's dog. 


\section{Hormonal GONTROL OF FAT METABOLISM}

A long series of experiments on this subject was started in 1930 and lasted till 1970. Although they were mainly carried out in dogs, some were made in other animal species.

The starting point was the demonstration by Rietti * that total pancreatectomy increased the elimination of ketonic bodies in the urine, and that, later, hypophysectomy diminished them. A new increase was obtained on the injection of extracts of anterior hypophyseal lobe into these doubly operated animals. This indicated that the control of fat metabolism was brought about by insulin and the hypophyseal hormones.

Further experiments carried out during the last 10 years by C. T. Rietti, E. Urgoiti, E. J. del Castillo, Alicia G. Roldán and María E. Galli have made the picture clearer still. They have shown that insulin takes part in the metabolism of fats on the one hand, while on the other hand hypophyseal hormones and the adrenal cortex act antagonistically. Thus diabetic ketosis is due to the lack of insulin and the balanced excess of hypophyseal and adrenal cortex hormones. Both factors in diabetes produce an increase in the destruction of fats and the mobilization of fat from the adipose tissues, and as a consequence there is an increase in the blood of free fatty acids, ketonemia and lipemia. The fatty liver and other tissues accumulated fats.

\section{The control of the Sexual FUNCTION}

Houssay's interest in the control of the sexual function in toads started in the old days of the Veterinary Faculty.

* Rietti, C. T.: Ketosis in the pancreatic diabetes of hypophysectomized dogs. Acta Congreso Internacional de Biología, Montevideo, 8: 332, 1930.
There he studied with Giusti the liberation of spermatozoa in the toad (Bufo arenarum Hensel) *. Many years later, now in the Institute of Biology and Experimental Medicine, he showed that the spermatozoa on their way out passed through the kidneys and escaped by the urine (M. Burgos, E. De Robertis and $\mathrm{O}$. Breytes).

Galli-Mainini proved that liberation of spermatozoa occurred in the toad if it was injected with urine from a pregnant woman. This reaction became very popular as a diagnostic test for pregnancy in women because of its efficiency, cheapness and simplicity, and it was able to replace the use of rabbits or rats. Although still used in many places, it has now been replaced by other techniques.

The publications of Houssay, E. del Castillo, G. di Paola, R. Sanmartino, R. M. Pinto, C. Galli-Mainini, etc., have shed light on this and other mechanisms in the control of the sexual function in batrachians.

\section{EXPERIMENTAL ARTERIAL HYPERTENSION}

The study of the factors which regulate the arterial blood pressure in normal and pathological states was another of the important lines of research conducted by Houssay.

Eduardo Braun-Menéndez was studying the part the kidney played in this regulation without any success when the fundamental work of $\mathrm{H}$. Goldblatt and his collaborators was published in U.S.A. (1943). Goldblatt showed that incomplete ligature of the renal artery produced arterial hypertension in the dog.

Houssay suggested to J. C. Fasciolo that he might throw some light on the mechanism by seeing if a graft of these

* The coincidence of the initials of the names of Houssay with those of the scientific name of this toad (B.A.H.) which he used so often gave rise to many jokes by his collaborators. 
Honorary President (5)

President of Honour (3)

Full Member (3)

Counsellor of Honour (1)

$\mathrm{He}$ was decorated 15 times and received 11 national and international prizes. Amongst these last was the Nobel Prize for Physiology and Medicine awarded him in 1947 *.

It is possible to make some remarks of historical import regarding the incredible argentine political situation when the authorities were surprised by the decision made by the Nobel Institute. All cultured and sensible argentines were delighted by the news. For the first time the Nobel Prize had been awarded to a scientist in Latin America. Nevertheless the dictatorship in power hindered the propagation of the news in all possible ways, they forbade its mention in newspapers or in the news bulletins in cinemas or over the radio; public meetings to celebrate the event were prohibited. Every effort was made to minimize the importance of the distinction. Houssay himself, with great modesty, considered the prize had been won by his collaborators and all who had shared his work as well. He felt that the prize obliged him to work ever harder and better along the same path and he also thought the intellectual

* "October 24, 1947. The Caroline Institute has decided to award the Nobel Prize for Physiology and Medicine for 1947 with one half to you for your discovery of the importance of the pituitary anterior lobe for the sugar metabolism and the other half to Professor Carl Cori and Doctor Gerty T. Cori jointly for their discovery of the course of the catalytic metabolism of glycogen. Hilding Bergstrand Rector". acknowledgement was a stimulus of benefit to his whole country. However he went on working in his usual manner.

\section{FINAL WORDS}

Houssay was a pioneer who developed scientific research where it did not exist. $\mathrm{He}$ thereby proved the falsity of the prejudices which declared the impossibility of research where there was no propitious environment, where there existed racial incapacity and where the economical difficulties appeared insuperable.

$\mathrm{He}$ was a self-made scientist, helped by a combination of outstanding personal qualities seldom possessed singly and even less all together. These qualities were his intelligence, his memory, his self-criticism, his physical strength, his love for science and his devotion to work, "which is the cheapest amusement", as he himself used to say.

He believed in justice and he believed in the future of his own country which he wished to see great.

Pasteur was right when he said: " $L a$ science n'a pas de patrie, ou plutôt, la patrie de la science est l'humanité toute entière". But Houssay knew that the scientist has his country and should work for it. He worked for his until his last moment, he fought and he conquered.

The life of Houssay comprising his battles, his sufferings and his victories is an example for the younger generations. He dedicated it to the good of his fellow-men and showed what can be achieved by capacity and work applied to a noble and high ideal.

Virgilio G. Foglia 